\title{
PENGARUH KONDISI KEUANGAN PERUSAHAAN, KUALITAS AUDIT DAN OPINION SHOPPING TERHADAP PENERIMAAN OPINI GOING CONCERN
}

\author{
Syamsuri Rahim ${ }^{1}$ \\ ${ }^{1}$ Fakultas Ekonomi Universitas Muslim Indonesia, Sulawesi Selatan, Indonesia \\ email: syamsurirahim@gmail.com
}

\begin{abstract}
ABSTRAK
Penelitian ini bertujuan untuk menguji pengaruh kondisi keuangan perusahaan, kualitas audit dan opinion shopping, terhadap opini going concern. Sampel yang digunakan dalam penelitian ini adalah perusahaan manufaktur yang terdaftar di Bursa Efek Indonesia tahun 2012-2014. Populasi penelitian ini sebanyak 132. Sampel penelitian berjumlah 28 yang dipilih dengan metode purposive sampling perusahaan dengan periode pengamatan 3 (tiga) tahun. Data dianalisis dengan menggunakan model analisis regresi logistik. Hasil penelitian menunjukkan bahwa kondisi keuangan, kualitas audit dan opinion shopping berpengaruh signifikan terhadap penerimaan opini audit going concern.
\end{abstract}

Kata kunci : Opini going concern, kondisi keuangan, kualitas audit, opinion shopping

\section{THE EF FECT OF COMPANY'S FINANCIAL CONDITION, THE AUDIT QUALITY AND SHOPPING OPINION TOWARDS THE ACCEPTANCE OF GOING CONCERN AUDIT OPINION}

\begin{abstract}
This study aims to examine the effect of the company's financial condition, the audit quality and shopping opinion towards the acceptance of going concern audit opinion. The samples used in this research are manufacturing companies listed in Indonesia Stock Exchange in 2012-2014. The population of this study is 132. The samples used are 28 companies selected by random sampling method during the observation period of 3 (three) years. Data was analyzed using logistic regression analysis model. The results show that the financial condition, audit quality and opinion shopping significantly influence the acceptance of going concern audit opinion.
\end{abstract}

Keywords: Going concern audit opinion, financial condition, audit quality, opinion shopping DOI : https://doi.org/10.24843/JIAB.2016.v11.i02.p02

\section{PENDAHULUAN}

Kelangsungan usaha selalu dikaitkan dengan kemampuan manajemen dalam mengelola perusahaan. Pada saat kondisi ekonomi suatu entitas tidak pasti, auditor diharapkan memberikan early warning kepada para investor akan kegagalan keuangan perusahaan. Auditor juga dapat memberikan opini audit going concern jika ada keraguan suatu entitas dalam menjalankan usahanya.

Opini going concern merupakan asumsi dalam pelaporan keuangan suatu entitas sehingga jika suatu entitas mengalami kondisi yang berlawanan dengan asumsi kelangsungan usaha, maka entitas tersebut dimungkinkan mengalami masalah untuk survive.
Sekalipun tujuan audit bukan untuk mengevaluasi kesehatan keuangan perusahaan, auditor memiliki tanggung jawab menurut SAS (AU 341) untuk mengevaluasi apakah perusahaan mempunyai kemungkinan untuk bertahan (Arens, 2008). Dengan kata lain, auditor bertanggung jawab untuk mengevaluasi apakah terdapat kesangsian besar terhadap kemampuan entitas dalam mempertahankan kelangsungan hidupnya dalam waktu tidak lebih dari satu tahun sejak tanggal laporan keuangan yang sedang diaudit (SPA 570; 2012)

Laporan audit dengan modifikasi going concern menunjukkan suatu indikasi bahwa terdapat risiko 
auditee tidak dapat bertahan lama. Dari sudut pandang auditor, keputusan tersebut melibatkan beberapa tahap analisis. Auditor harus mempertimbangkan kondisi ekonomi yang mempengaruhi perusahaan, hasil dari operasi perusahaan, kemampuan membayar hutang serta kebutuhan likuidasi di masa mendatang (Setyarno, et. al., 2006).

Terkait dengan pentingnya opini audit yang dikeluarkan auditor, maka auditor harus bertanggung jawab untuk mengeluarkan opini audit going concern yang sesuai dengan kondisi perusahaan sebenarnya. Ada beberapa faktor yang dapat dikaji sebagai faktor yang berpengaruh terhadap penerimaan opini audit going concern yaitu kondisi keuangan perusahaan, kualitas audit, dan opinion shopping.

Pada perusahaan yang kondisi keuangannya baik, auditor cenderung untuk tidak mengeluarkan opini audit going concern (Ramadhany, 2004). Hal ini didukung oleh Carcello, et. al., (2000) yang menyebutkan bahwa kondisi keuangan perusahaan yang terganggu, maka besar kemungkinan perusahaan tersebut akan menerima opini audit going concern. Pendapat tersebut juga didukung oleh Setyarno, et. al., (2006), Santoso dan Wedari (2007) serta Rudyawan dan Badera (2009) yang menyatakan bahwa, semakin baik kondisi keuangan perusahaan semakin kecil kemungkinan auditor memberikan opini audit going concern.

Sementara itu, pengukuran kualitas audit masih tetap merupakan sesuatu yang tidak jelas, tetapi pemakai laporan keuangan biasa mengaitkannya dengan reputasi auditor. Teoh dan Wong, (1993) dan Craswell, et. al., (1995) menyatakan, klien biasanya mempersepsikan bahwa auditor yang berasal dari KAP besar dan yang memiliki afiliasi dengan KAP internasional akan memiliki kualitas yang lebih tinggi, karena auditor tersebut memiliki karakteristik yang dapat dikaitkan dengan kualitas seperti pelatihan, pengakuan internasional, dan adanya peer review. Auditor yang memiliki reputasi yang baik akan cenderung untuk mempertahankan kualitas auditnya agar reputasinya terjaga dan tidak kehilangan klien.

Faktor lain yang berpengaruh dalam penerimaan opini audit going concern ialah opinion shopping. Security Exchange Commisiion (SEC) mendefinisikan opinion shopping adalah aktivitas mencari auditor yang mau mendukung cara perlakuan akuntansi yang dilakukan oleh manajemen untuk mencapai tujuan pelaporan perusahaan. Perusahaan biasanya melakukan pergantian auditor untuk menghindari penerimaan opini going concern. Tujuan melakukan opinion shopping adalah untuk meningkatkan hasil operasi atau kondisi keuangan perusahaan.

Penelitian ini mengacu pada penelitian Aiisiah dan Sugeng (2012). Perbedaan penelitian ini adalah penggantian salah satu variabel dengan variabel opinion shopping. Variabel opinion shopping dipilih karena dianggap dapat menjadi salah satu faktor penting penentu suatu perusahaan ketika akan menerima opini audit dari auditor. Opinion shopping memungkinkan manajemen perusahaan untuk mengganti auditornya ke auditor lain apabila perusahaannya memiliki kemungkinan besar akan menerima opini audit going concern dari auditor yang sedang bertugas (Praptitorini dan Januarti, 2007).

Opini audit going concern adalah opini yang dikeluarkan oleh auditor untuk mengevaluasi apakah ada kesangsian tentang kemampuan perusahaan untuk mempertahankan kelangsungan hidupnya (SPA 570; 2012). Laporan audit dengan modifikasi mengenai going concern merupakan suatu indikasi bahwa dalam penilaian auditor terdapat risiko auditee tidak dapat bertahan dalam bisnis. Dari sudut pandang auditor, keputusan tersebut melibatkan beberapa tahap analisis. Auditor harus mempertimbangkan hasil dari operasi, kondisi ekonomi yang mempengaruhi perusahaan, kemampuan membayar hutang, dan kebutuhan likuiditas di masa yang akan datang.

Menurut Standar Perikatan Audit (SPA 570; 2012), going concern adalah berhubungan dengan ketidak mampuan entitas dalam memenuhi kewajibannya pada saat jatuh tempo tanpa melakukan penjualan sebagian besar aktiva kepada pihak luar melalui bisnis biasa, restrukrisasi utang, perbaikan operasi yang dipaksakan dari luar dan kegiatan lainnya. Sedangkan menurut IAS (paragraph 7) dalam Internasional Auditing Guideline Juni 1986, going concern didefinisikan sebagai berikut:

"The enterprise is normally viewed as a going concern, that is as continuing in operasion for foreseeable future, it is assumed that the enterprise has neither the intention nor the necessary of liquidation or of curtailing materially the scale of this operations."

Kondisi keuangan perusahaan menggambarkan tingkat kesehatan perusahaan kenyataannya (Ramadhany, 2004). Kondisi keuangan perusahaan juga mencerminkan kelangsungan kinerja suatu perusahaan kedepannya. Melalui laporan keuangan, para pengguna laporan keuangan dapat mengetahui 
kondisi keuangan suatu perusahaan dan dapat memprediksi apakah perusahaan tersebut akan tetap bertahan kedepannya. McKeown et. al., (1991) menyatakan bahwa semakin buruk kondisi perusahaan maka akan semakin besar kemungkinan pengungkapan opini audit going concern, begitu pula sebaliknya.

Penelitian Carcello dan Neal (2000) mengenai komposisi komite audit dan laporan auditor menyatakan bahwa semakin buruk kondisi keuangan perusahaan maka akan semakin besar peluang pengungkapan opini audit going concern oleh auditor. Temuan tersebut selaras dengan penelitian Margaretta dan Sylvia (2005), Eko, et. al., (2006), serta Arga dan Linda (2007) yang menunjukkan bahwa model prediksi kebangkrutan sebagai proksi dari kondisi keuangan perusahaan berpengaruh pada kemungkinan pengungkapan opini audit going concern.

Sebagaimana dijelaskan oleh De Angelo (1981) bahwa kualitas audit adalah probabilitas dimana seorang auditor menemukan dan melaporkan tentang adanya suatu pelanggaran dalam sistem akuntansi auditenya. Deis dan Groux (1992) menjelaskan bahwa probabilitas untuk menemukan pelanggaran tergantung pada kemampuan teknis auditor dan probabilitas melaporkan pelanggaran tergantung pada independensi auditor. Kompetensi dan independensi yang dimiliki auditor dalam penerapannya akan terkait dengan etika. Akuntan mempunyai kewajiban untuk menjaga standar perilaku etis tertinggi mereka kepada organisasi dimana mereka bernaung, profesi mereka, masyarakat dan diri mereka sendiri dimana akuntan mempunyai tanggungjawab menjadi kompeten dan untuk menjaga integritas dan obyektivitas mereka (Nugrahaningsih, 2005).

Watkins, et al., (2004) telah mengidentifikasi empat buah definisi kualitas audit dari beberapa ahli, yaitu sebagai berikut; a) Kualitas audit adalah probabilitas nilaian-pasar bahwa laporan keuangan mengandung kekeliruan material dan auditor akan menemukan dan melaporkan kekeliruan material tersebut; b) Kualitas audit merupakan probabilitas bahwa auditor tidak akan melaporkan laporan audit dengan opini wajar tanpa pengecualian untuk laporan keuangan yang mengandung kekeliruan material; c) Kualitas audit diukur dari akurasi informasi yang dilaporkan oleh auditor; d)Kualitas audit ditentukan dari kemampuan audit untuk mengurangi noise dan bias dan meningkatkan kemurnian pada data akuntansi.

Security Exchange Commisision (1985) mendifinisikan opinion shopping sebagai aktivitas mencari auditor yang mau mendukung perlakuan akuntansi yang diajukan oleh manajemen untuk mencapai tujuan pelaporan perusahaan. Perusahaan biasanya melakukan pergantian auditor untuk menghindari penerimaan opini going concern. Teoh (1992) menjelaskan bahwa perusahaan biasanya melakukan pergantian auditor dengan dua cara untuk menghindari opini going concern. Perusahaan dapat mengancam melakukan pergantian auditor. Dengan ancaman tersebut, indepensi auditor akan menurun sehingga tidak mampu mengungkapkan masalah perusahaan. Bahkan ketika auditor tersebut independen, perusahaan akan memberhentikan akuntan publik (auditor) yang cenderung memberikan opini going concern, atau sebaliknya akan menunjuk auditor yang cenderung memberikan opini non going concern. Tindakan ini ini disebut opinion shopping.

Opinion shopping dilakukan untuk mendapat opini audit yang lebih baik. Hal inilah yang mendasari perusahaan untuk berpindah auditor. Praktik opinion shopping dapat terlihat dari opini audit baru yang diperoleh perusahaan. Pada umumnya setelah berpindah auditor independen, maka perusahaan akan mendapatkan opini audit yang lebih baik.

Kelangsungan hidup suatu usaha selalu dihubungkan dengan kemampuan manajemen dalam mengelola perusahaan agar dapat bertahan. Ketika suatu perusahaan mengalami permasalahan keuangan (financial distress), kegiatan operasional perusahaan akan terganggu yang akhirnya dapat berdampak pada tingginya risiko yang dihadapi perusahaan dalam mempertahankan kelangsungan hidup usahanya di masa mendatang, hal ini akan berpengaruh terhadap opini audit yang diberikan oleh auditor. Jika perusahaan tidak mengalami permasalahan keuangan maka auditor akan cenderung tidak mengeluarkan opini audit going concern (Ramadhany, 2004). Santosa dan Wedari (2007) yang menemukan bukti bahwa kondisi perusahaan yang baik atau tidak mengalami kesulitan keuangan maka kemungkinan kecil akan mendapat opini going concern.

Penelitian Setyarno et. al., (2006) dengan menggunakan regresi logistik menunjukkan bahwa variabel kondisi keuangan dengan menggunakan The Altman Model berpengaruh signifikan terhadap penerimaan opini audit going concern. Hasil penelitian ini konsisten dengan penelitian sebelumnya yang dilakukan oleh Ramadhany (2004) yang memberikan bukti bahwa auditor hampir tidak pernah memberikan opini audit going concern pada perusahaan yang tidak mengalami kesulitan 
keuangan. Berdasarkan uraian diatas, maka hipotesis pertama yang diajukan adalah sebagai berikut:

$\mathrm{H}_{1}$ : Kondisi keuangan perusahaan berpengaruh negatif terhadap penerimaan opini going concern.

Reputasi auditor sering digunakan sebagai proksi dari kualitas audit, namun demikian dalam banyak penelitian kompetensi dan independensi masih jarang digunakan untuk melihat seberapa besar kualitas audit secara aktual (Ruiz et. al., 2004). Reputasi auditor didasarkan pada kepercayaan pemakai jasa auditor bahwa auditor memiliki kekuatan monitoring yang secara umum tidak dapat diamati. DeAngelo (1981) menyatakan bahwa auditor skala besar memiliki insentif yang lebih untuk menghindari kritikan kerusakan reputasi dibandingkan pada auditor skala kecil. Auditor skala besar juga lebih cenderung untuk mengungkapkan masalah -masalah yang ada karena mereka lebih kuat menghadapi risiko proses pengadilan. Argumen tersebut berarti bahwa auditor skala besar memiliki insentif lebih untuk mendeteksi dan melaporkan masalah going concern kliennya.

Mutchler dan McKeown (1997) menemukan bukti univariat bahwa auditor big 6 lebih cenderung menerbitkan opini audit going concern pada perusahaan yang mengalami financial distress dibandingkan auditor non big 6 . Auditor skala besar dapat menyediakan kualitas audit yang lebih baik dibanding auditor skala kecil, termasuk dalam mengungkapkan masalah going concern. Semakin besar skala auditor, akan semakin semakin besar kemungkinan auditor untuk menerbitkan opini audit going concern.

Dalam penelitian Crasswell, et. al., (1995) dan Setyarno, et al. (2006) kualitas auditor diukur dengan menggunakan ukuran auditor specialization. Crasswell, et al. (1995) menunjukkan bahwa spesialisasi auditor pada bidang tertentu merupakan dimensi lain dari kualitas audit. Hasil penelitiannya menunjukkan bahwa fee audit spesialis lebih tinggi dibandingkan auditor non spesialis. Mayangsari (2003) melakukan penelitian pengaruh spesialisasi industri auditor sebagai proksi lain dari kualitas audit terhadap integritas laporan keuangan. Hasil penelitiannya menunjukkan bahwa spesialisasi auditor berpengaruh positif terhadap integritas laporan keuangan. Berdasarkan uaraian di atas, maka hipotesis kedua yang diajukan adalah sebagai berikut:

$\mathrm{H}_{2}$ : Kualitas audit berpengaruh positif terhadap penerimaan opini going concern.
Teori agensi menyebutkan bahwa hubungan antara prinsipal dan agen dapat mengarah pada kondisi ketidakseimbangan informasi. Hal ini terjadi karena agen memiliki informasi yang lebih banyak tentang perusahaan dibandingkan dengan prinsipal. Dengan demikian, diasumsikan bahwa individuindividu dalam perusahaan bertindak untuk memaksimalkan kepentingan diri sendiri. Adanya asimetri informasi mendorong agen untuk menyembunyikan beberapa informasi yang tidak diketahui prinsipal.

Sedangkan dalam teori atribusi dijelaskan bahwa seseorang akan cenderung menghindari risiko, sehingga dapat diasumsikan bahwa agen akan melakukan berbagai cara agar terhindar dari risiko pemecatan ketika kinerja perusahaan yang dirisiko pemecatan ketika kinerja perusahaan yang dicerminkan dalam laporan keuangan terpuruk. Agen dapat menekan auditor untuk memberikan opini audit yang sesuai dengan keinginan agen agar laporan keuangan dapat terlihat baik oleh pengguna laporan keuangan. Kegiatan menekan auditor ini merupakan salah satu bentuk kegiatan opinion shopping.

Pada kondisi keterbatasan informasi yang dimiliki prinsipal, agen dapat melakukan berbagai cara untuk mendapat penilaian yang baik dari prinsipal atas kinerjanya. Salah satu cara yang dapat dilakukan agen adalah dengan melakukan opinion shopping. Opinion shopping seperti yang didefinisikan oleh SEC sebagai aktivitas mencari auditor yang mau mendukung perlakuan akuntansi yang diajukan oleh manajemen untuk mencapai tujuan pelaporan perusahaan. Tujuannya adalah memanipulasi hasil operasi atau kondisi keuangan. Berdasarkan uraian di atas maka hipotesis ketiga yang diajukan adalah sebagai berikut:

$\mathrm{H}_{3}$ : Opinion shopping berpengaruh negatif terhadap penerimaan opini going concern.

\section{METODE PENELITIAN}

Populasi dalam penelitian ini adalah seluruh perusahaan manufaktur yang terdaftar di Bursa Efek Indonesia (BEI) yang terdapat di Makassar tahun 2012-2014. Pengambilan sampel penelitian ini dilakukan dengan menggunakan metode purposive sampling yaitu penentuan sampel dengan kriteria tertentu. Metode pengumpulan data yang digunakan dalam penelitian ini adalah metode dokumentasi dari data-data yang dipublikasikan oleh perusahaan mengenai laporan keuangan perusahaan dari Bursa Efek Indonesia (BEI) Makassar. Data dalam penelitian ini menggunakan data sekunder, yaitu data 
tidak langsung. Data sekunder dalam penelitian ini diperoleh dari laporan keuangan perusahaan yang telah dipublikasikan yang diambil dari Bursa Efek Indonesia.

Pengujian terhadap hipotesis dalam penelitian ini menggunakan analisis regresi logistik (logistic regression). Menurut Ghozali (2011) analisis regresi logistik cocok untuk penelitian yang variabelnya bersifat kategorikal (nominal atau non metrik) dan variabel independennya kombinasi antara metrik dan non metrik. Analisis regresi logistik tidak memerlukan asumsi normalitas pada data data variabel bebasnya. Analisis regresi logistik digunakan untuk menguji apakah variabel-variabel kondisi keuangan perusahaan, kualitas audit, dan opinion shopping berpengaruh terhadap penerimaan opini audit going concern. Model regresi yang dikembangkan dalam penelitian ini adalah sebagai berikut:

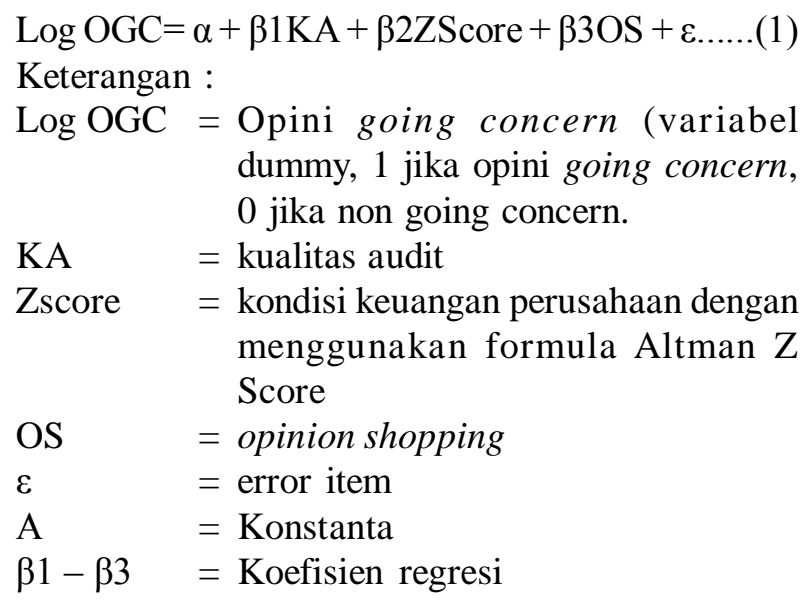
dummy, 1 jika opini going concern, 0 jika non going concern.

KA $\quad=$ kualitas audit

Zscore $=$ kondisi keuangan perusahaan dengan menggunakan formula Altman $\mathrm{Z}$ Score

OS = opinion shopping

$\varepsilon \quad=$ error item

$\mathrm{A}=$ Konstanta

$\beta 1-\beta 3=$ Koefisien regresi

\section{HASIL DAN PEMBAHASAN}

Berdasarkan hasil statistik deskriptif dari data yang diolah, diperoleh hasil sebagai berikut.

Tabel 1.

\section{Hasil Uji Statistik Deskriptif}

\begin{tabular}{lrrrrr}
\hline & N & \multicolumn{1}{c}{ Minimum } & \multicolumn{1}{c}{ Maximum } & Mean & \multicolumn{1}{c}{ Std. Deviation } \\
\hline Going Concern & 84 & 0 & 1 & 0,600 & 0,494 \\
Kualitas audit & 84 & 0 & 1 & 0,320 & 0,470 \\
Opinion Shopping & 84 & 0 & 1 & 0,500 & 0,503 \\
Kondisi Keuangan & 84 & $-4,05$ & 20,98 & 1,592 & 3,072 \\
Valid N (listwise) & 84 & & & & \\
\hline
\end{tabular}

Sumber : Data diolah, 2016

Berdasarkan tabel diatas maka dapat dilihat bahwa variabel going concern dari 84 data didapatkan nilai mean 0,60 nilai minimum sebesar 0 sedangkan nilai maximum yaitu 1 dan standar deviasi sebesar 0,494. Variabel kondisi keuangan dari 84 data didapatkan nilai mean 1,59 nilai minimum sebesar $-4,05$ sedangkan nilai maximum yaitu 20,98 dan standar deviasi sebesar 3,07213. Variabel kualitas audit dari 84 data didapatkan nilai mean 0,32 nilai minimum sebesar 0 sedangkan nilai maximum yaitu 1 dan standar deviasi sebesar 0,470. Variabel opinion shopping dari 84 data didapatkan nilai mean 0,50 nilai minimum sebesar 0 sedangkan nilai maximum yaitu 1 dan standar deviasi sebesar 0,503 .

Berdasarkan hasil pengujian untuk menilai kelayakan model regresi, dapat dilihat pada tabel 2 sebagai berikut:

Tabel 2.

Uji Hosmer and Lemeshow Goodness of Fit Test

\begin{tabular}{ccccc}
\hline Step & Chi-square & df & \multicolumn{1}{c}{ Sig. } \\
\hline 1 & 22,188 & 8 & & 0,387 \\
\hline
\end{tabular}

Sumber : Data diolah, 2016

Berdasarkan hasil di atas dapat diketahui bahwa nilai statistik Hosmer and Lemeshow's Goodness of Fit sebesar 22,188. Hasil statistik tersebut mempunyai signi-fikansi $0,387>0,05$, sehingga dapat disimpulkan bahwa persamaan regresi logit pada penelitian ini mempunyai model yang fit dengan data. Menilai Keseluruhan Model (Overall Model Fit)

Tabel 3.

Hasil uji Model Overall Model Fit

\begin{tabular}{crrr}
\hline Step & -2 Log likelihood & Cox \& Snell R Square & \multicolumn{2}{c}{ Nagelkerke R Square } \\
\hline 1 & $54,916^{\mathrm{a}}$ & 0,501 & 0,677 \\
\hline
\end{tabular}

Sumber : Data diolah, 2016 
Berdasarkan tabel diatas menunjukkan bahwa nilai -2 Log likelihood sebelum 113,382 dan nilai -2 Log likelihood tabel diatas sebesar 54,918 maka nilai overall model fitnya dengan rumusan $2 \operatorname{LogL}$ sebelumnya
-2LogL sesudah maka 113,382-54,918 = 58,464 maka dapat disimpulkan bahwa nilai Log likelihood semakin menurun maka semakin baik model tersebut. oefisien Determinasi (Nagelkerke R Square)

Tabel 4.

Hasil uji SPSS Nagelkerke R Square

\begin{tabular}{rrrr}
\hline Step & -2 Log likelihood & Cox \& Snell R Square & \multicolumn{2}{c}{ Nagelkerke R Square } \\
\hline 1 & $54,916^{\mathrm{a}}$ & 0,501 & 0,677 \\
\hline
\end{tabular}

Sumber : Data diolah, 2016

Tabel di atas menunjukkan nilai Nagelkerke's $R$ Square sebesar 0,501. Hal ini berarti bahwa variabilitas variabel terikat yang dapat dijelaskan oleh variabel bebas sebesar 50,1\%. Adapun 49,9\% dipengaruhi oleh faktor lain di luar model.

Tabel 5.

Hasil Pengujian Hipotesis Regresi Logistik

\begin{tabular}{|c|c|c|c|c|c|c|c|c|c|}
\hline & & \multirow[t]{2}{*}{ B } & \multirow[t]{2}{*}{ S.E. } & \multirow[t]{2}{*}{ Wald } & \multirow[t]{2}{*}{ Df } & \multirow[t]{2}{*}{ Sig. } & \multirow[t]{2}{*}{$\operatorname{Exp}(B)$} & \multicolumn{2}{|c|}{$\begin{array}{c}\text { 95\% C.I.for } \\
\text { EXP(B) }\end{array}$} \\
\hline & & & & & & & & Lower & Upper \\
\hline \multirow{4}{*}{ Step $1^{\mathrm{a}}$} & $\mathrm{KA}(1)$ & $-1,454$ & 1,051 & 1,915 & 1 & 0,016 & 0,234 & 0,030 & 1,832 \\
\hline & OS(1) & $-1,992$ & 0,872 & 5,223 & 1 & 0,022 & 0,136 & 0,025 & 0,753 \\
\hline & $\mathrm{Z}$ & $-1,533$ & 0,440 & 12,159 & 1 & 0,000 & 0,216 & 0,091 & 0,511 \\
\hline & Constant & 4,868 & 1,168 & 17,372 & 1 & 0,000 & 130,023 & & \\
\hline
\end{tabular}

Sumber : Data diolah, 2016

Berdasarkan hasil di atas menujukkan variabel kondisi keuangan menunjukkan nilai koefisien regresi negatif sebesar $-1,533$ dengan tingkat signifikansi 0,000 lebih kecil dari 0,05 . Nilai signifikansi yang lebih kecil dari 0,05 berarti dapat disimpulkan bahwa variabel kondisi keuangan berpengaruh pada penerimaan opini going concern sehingga $\mathrm{H}_{1}$ diterima. Hasil menujukkan variabel kualitas audit menunjukkan nilai koefisien regresi negatif sebesar -1,454 dengan tingkat signifikansi 0,016 lebih kecil dari 0,05. Nilai signifikansi yang lebih kecil dari 0,05 berarti dapat disimpulkan bahwa variabel kualitas audit berpengaruh pada penerimaan opini going concern sehingga $\mathrm{H}_{2}$ diterima. Temuan juga menujukkan variabel opinion shopping menunjukkan nilai koefisien regresi negatif sebesar $-1,992$ dengan tingkat signifikansi 0,022 lebih kecil dari 0,05. Nilai signifikansi yang lebih kecil dari 0,05 berarti dapat disimpulkan bahwa variabel opinion shopping berpengaruh pada penerimaan opini going concern sehingga $\mathrm{H}_{3}$ diterima.

Berdasarkan hasil diatas yang telah dijelaskan sebelumnya menujukkan variabel kondisi keuangan menunjukkan nilai koefisien regresi negatif sebesar $-1,533$ dengan tingkat signifikansi 0,000 lebih kecil dari 0,05. Nilai signifikansi yang lebih kecil dari 0,05 berarti dapat disimpulkan bahwa variabel kondisi keuangan berpengaruh signifikan pada penerimaan opini going concern sehingga $\mathrm{H}_{1}$ diterima. .

Hal ini menunjukkan bahwa kondisi keuangan yang baik dapat mempengaruhi kelangsungan hidup suatu usaha dimana kelangsungan hidup suatu usaha selalu dihubungkan dengan kemampuan manajemen dalam mengelola perusahaan agar dapat bertahan. Ketika suatu perusahaan mengalami permasalahan keuangan (financial distress), kegiatan operasional perusahaan akan terganggu yang akhirnya dapat berdampak pada tingginya risiko yang dihadapi perusahaan dalam mempertahankan kelangsungan hidup usahanya di masa mendatang, hal ini akan berpengaruh terhadap opini audit yang diberikan oleh auditor. Jika perusahaan tidak mengalami permasalahan keuangan maka auditor akan cenderung tidak mengeluarkan opini audit going concern (Ramadhany, 2004). Santosa dan Wedari (2007) yang menemukan bukti bahwa kondisi perusahaan yang baik atau tidak mengalami kesulitan keuangan maka kemungkinan kecil akan mendapat opini going concern.

Penelitian Setyarno et. al., (2006) dengan menggunakan regresi logistik menunjukkan bahwa variabel kondisi keuangan dengan menggunakan The Altman Model berpengaruh signifikan terhadap penerimaan opini audit going concern. Hasil 
penelitian ini konsisten dengan penelitian sebelumnya yang dilakukan oleh Ramadhany (2004) yang memberikan bukti bahwa auditor hampir tidak pernah memberikan opini audit going concern pada perusahaan yang tidak mengalami financial distress begitupun sebaliknya.

Dalam penelitian ini kualitas audit diproksikan dengan menggunakan ukuran KAP. Variabel ini diukur dengan menggunakan variabel dummy. Kode 1 diberikan pada perusahaan yang menggunakan jasa KAP yang berafiliasi dengan the big four, sedangkan perusahaan yang menggunakan jasa KAP yang tidak berafiliasi dengan the big four diberi kode 0 .

Berdasarkan hasil diatas menujukkan variabel kualitas audit menunjukkan nilai koefisien regresi negatif sebesar $-1,454$ dengan tingkat signifikansi 0,016 lebih kecil dari 0,05 . Nilai signifikansi yang lebih kecil dari 0,05 berarti dapat disimpulkan bahwa variabel kualitas audit berpengaruh signifikan pada penerimaan opini going concern sehingga $\mathrm{H}_{2}$ diterima. Hal ini mengindikasikan bahwa reputasi sebuah Kantor Akuntan Publik mencerminkan kualitas dari jaminan yang diberikannya, besar kecilnya sebuah KAP mempengaruhi besar kecilnya kemungkinan KAP tersebut untuk mengeluarkan opini audit going concern.

Mutchler et. al., (1997) menemukan bukti univariat bahwa auditor big 4 lebih cenderung menerbitkan opini audit going concern pada perusahaan yang mengalami financial distress dibandingkan auditor non big 4. Auditor skala besar dapat menyediakan kualitas audit yang lebih baik dibanding auditor skala kecil, termasuk dalam mengungkapkan masalah going concern. Semakin besar skala auditor, akan semakin semakin besar kemungkinan auditor untuk menerbitkan opini audit going concern.

Dalam penelitian Crasswell, et. al., (1995) dan Setyarno, et. al., (2006), kualitas auditor diukur dengan menggunakan ukuran auditor specialization. Crasswell menunjukkan bahwa spesialisasi auditor pada bidang tertentu merupakan dimensi lain dari kualitas audit. Hasil penelitiannya menunjukkan bahwa fee audit spesialis lebih tinggi dibandingkan auditor non spesialis. Mayangsari (2003) melakukan penelitian pengaruh spesialisasi industri auditor sebagai proksi lain dari kualitas audit terhadap integritas laporan keuangan. Hasil penelitiannya menunjukkan bahwa spesialisasi auditor berpengaruh positif terhadap integritas laporan keuangan. Hasil penelitian ini konsisten dengan hasil penelitian sebelumnya bahwa besar kecilnya skala auditor dalam hal ini yang berafiliasi dengan The Big Four akan mempengaruhi kecendrungan dikeluarkannya suatu opini going concern.

Berdasarkan hasil diatas menujukkan variabel opinion shopping menunjukkan nilai koefisien regresi negatif sebesar -1,992 dengan tingat signifikansi 0,022 lebih kecil dari 0,05. Nilai signifikansi yang lebih kecil dari 0,05 berarti dapat disimpulkan bahwa variabel opinion shopping berpengaruh signifikan pada penerimaan opini going concern sehingga $\mathrm{H}_{3}$ diterima.

Hal ini menunjukkan bahwa opinion shopping dilakukan untuk mendapat opini audit yang lebih baik. Hal inilah yang mendasari perusahaan untuk berpindah auditor. Praktik opinion shopping dapat terlihat dari opini audit baru yang diperoleh perusahaan. Pada umumnya setelah berpindah auditor independen, maka perusahaan akan mendapatkan opini audit yang lebih baik.

Dalam teori agensi menyebutkan bahwa hubungan antara prinsipal dan agen dapat mengarah pada kondisi ketidakseimbangan informasi. Hal ini terjadi karena agen memiliki informasi yang lebih banyak tentang perusahaan dibandingkan dengan prinsipal. Dengan demikian, diasumsikan bahwa individu-individu dalam perusahaan bertindak untuk memaksimalkan kepentingan diri sendiri. Adanya asimetri informasi mendorong agen untuk menyembunyikan beberapa informasi yang tidak diketahui prinsipal. Sedangkan dalam teori atribusi dijelaskan bahwa seseorang akan cenderung menghindari risiko, sehingga dapat diasumsikan bahwa agen akan melakukan berbagai cara agar terhindar dari risiko pemecatan ketika kinerja perusahaan yang dirisiko pemecatan ketika kinerja perusahaan yang dicerminkan dalam laporan keuangan terpuruk. Agen dapat menekan auditor untuk memberikan opini audit yang sesuai dengan keinginan agen agar laporan keuangan dapat terlihat baik oleh pengguna laporan keuangan. Kegiatan menekan auditor ini merupakan salah satu bentuk kegiatan opinion shopping.

Pada kondisi keterbatasan informasi yang dimiliki prinsipal, agen dapat melakukan berbagai cara untuk mendapat penilaian yang baik dari prinsipal atas kinerjanya. Salah satu cara yang dapat dilakukan agen adalah dengan melakukan opinion shopping. Opinion shopping seperti yang didefinisikan oleh SEC sebagai aktivitas mencari auditor yang mau mendukung perlakuan akuntansi yang diajukan oleh manajemen untuk mencapai tujuan pelaporan perusahaan. Tujuannya adalah memanipulasi hasil operasi atau kondisi keuangan. 


\section{SIMPULAN}

Berdasarkan hasil temuan penelitian dari semua hipotesis yang diuji dengan menggunakan regresi logistik disimpulkan bahwa semua hipotesis diterima. Temuan ini menunjukkan bahwa Kondisi keuangan berpengaruh terhadap penerimaan opini going concern, kualitas audit berpengaruh terhadap penerimaan opini going concern, dan opinion shopping berpengaruh terhadap penerimaan opini going concern. Dari temuan tersebut dapat dijelaskan bahwa penerimaan opini going concern ditentukan oleh kondisi keuangan perusahaan, kualitas laporan keuangan dan opinion shopping.

Agar dapat lebih menjaga kinerjanya dengan baik variabel keberadaan komite audit dan komisaris independen tidak dilihat dari jumlahnya, tetapi dari keahlian yang dimiliki (misal : pengalaman maupun pendidikan) dan keaktifan mereka di perusahaan (misal : frekuensi keterlibatan mereka dalam rapatrapat perusahaan). Pada penelitian selanjutnya dapat menambah variabel keuangan dan non keuangan lainnya sehingga hasil penelitian akan lebih bisa memprediksi penerbitan opini audit going concern. Penelitian selanjutnya dapat memperluas sampel penelitian dan periode pengamatan dengan memasukkan industri perbankan, industri jasa, transportasi, dan lain sebagainya yang dijadikan objek penelitian.

\section{REFERENSI}

Aiisiah, N., \& P. Sugeng, (2012). Pengaruh Kualitas audit, Kondisi Keuangan Perusahaan, Opini Audit Tahun Sebelumnya, Pertumbuhan Perusahaan Terhadap Kecenderungan Penerimaan Opini Audit Going Concern. Dipenogoro Journal of Accounting, 1(1), 113

Arens, A. A, R. J. Elder, \& M. S. Beasley. (2008). Auditing dan Jasa Assurance. Penerbit Erlangga, Jakarta.

Arga, F. S., \& L. K. Wedari. (2007). Analisis FaktorFaktor yang Mempengaruhi Kecenderungan Penerimaan Opini Audit Going Concern. Jurnal Akuntansi \& Auditing Indonesia, 11(2), 141158.

Carcello, J.V., \& Neal, T.L. 2000. Audit Committee Composition and Auditor Reporting. The Accounting Review, 75(4), 453-467.

Craswell, Allen T., Jere R. Francis, \& Stephen L. Taylor. (1995). Auditor Brand Name Reputations and Industry Specialization. Journal of Accounting and Economics, 20, 297-322.
DeAngelo, L. E. (1981). Auditor Size and Audit Quality. Journal of Accounting and Economics, 3, 183-199.

Deis, D.R., \& G.A. Groux. (1992). Determinants of Audit Quality in The Public Sector. The Accounting Review, 462-479

Departemen Keuangan Republik Indonesia. (2008). Lehman Brothers dan Reformasi Birokrasi DJA.

Eko, B. S., I. Januarti, \& Faisal. (2006). Pengaruh Kualitas Audit, Kondisi Keuangan Perusahaan, Opini Audit Tahun Sebelumnya, Pertumbuhan Perusahaan terhadap Opini Audit Going Concern. Prosiding, Disampaikan pada Simposium Nasional Akuntansi (SNA) IX Padang.

Ghozali. (2011). Aplikasi Analisis Multivariate Dengan Program IBM SPSS 19. Penerbit Universitas Diponegoro. Semarang.

Ikatan Akuntansi Indonesia. (2001). Standar Profesional Akuntan Publik. Penerbit Salemba Empat, Jakarta.

Indriantoro dan B. Supomo.(1999). Metodologi Penelitian Bisnis Untuk Akuntansi dan Manajemen. Penerbit BPFE, Yogyakarta.

Margaretta, F., \& S. Saputra. (2005). Opini Audit Going Concern: Kajian Berdasarkan Model Prediksi Kebangkrutan, Pertumbuhan Perusahaan, dan Reputasi Kantor Akuntan Publik (Studi pada Emiten Bursa Efek Jakarta). Prosiding, disampaikan pada Simposium Nasional Akuntansi (SNA) VIII Solo.

Mayangsari, S. (2003). Pengaruh Kualitas Audit, Independensi terhadap Integritas Laporan Keuangan. Prosiding, disampaikan pada Simposium Nasional Akuntansi VI. Surabaya.

McKeown, J.R., Jane F.Mutchler, \& W. Hopwood. (1991). Toward an Explanation of Auditor Failure to Modify the Audit Reports of Bankrupt Companies. Auditing: A Journal of Practice and Theory. Supplement: 1-13.

Mulyadi. (2002). Auditing. Buku 2. Penerbit Salemba Empat. Yogyakarta.

Mutchler, W. H., \& J. M. McKeown. (1997). The Influence of Contrary Information and Mitigating Factors on Audit Opinion Decisions on Bankrupt Companies. Journal of Accounting Research. 35(2), 295-310.

Nugrahaningsih, P. (2005). Analisis Perbedaan Perilaku Etis Auditor di KAP dalam Etika Profesi (Studi Terhadap Peran Faktor-faktor Individual: Locus of Control, Lama Pengalaman Kerja, Gender, dan Aquity Sensitivity). Prociding, disampaikan pada Simposium Nasional Akuntansi VIII, Solo. 
Praptitorini, M.D., \& I. Januarti. (2007). Analisis Pengaruh Kualitas Audit, Debt Default, dan Opinion Shopping terhadap Penerimaan Opini Going Concern. Prosiding, disampaikan dalam Simposium Nasional Akuntansi X. Makassar: 26-28 Juli.

Ramadhany, A. (2004). Analisis Faktor - Faktor Yang Mempengaruhi Penerimaan Opini Going Concern Pada Perusahaan Manufaktur Yang Mengalami Financial Distress Di Bursa Efek Jakarta. Tesis. Universitas Diponegoro, Semarang.

Rudyawan, A.P., \& I.DN. Badera, (2009). Opini Audit Going Concern: Kajian Berdasarkan Model Prediksi Kebangkrutan, Pertumbuhan Perusahaan, Leverage, dan Reputasi Auditor, Jurnal Ilmiah Akuntansi dan Bisnis, 4(2).

Ruiz, B. E., N.Gomez-Aguilar, C.D. Fuentes-Barbera dan M. A. Garcia-Benau. 2004. Audit Quality and The Going Concern Decision Making Process. European Accounting Review, 13(4), 597-620.

Sekaran, Uma (2006). Metodologi Penelitian untuk Bisnis, Edisi Keempat, Jakarta: Salemba Empat.
Santoso, A. F., Wedari, L. K. (2007). Analisis FaktorFaktor yang Mempengaruhi Kecenderungan Penerimaan Opini Audit Going Concern. Jurnal Akuntansi dan Auditing Indonesia, 11(2), 141158. UNIKA Soegijapranata. Semarang.

Setiawan, S. 2006. Opini Going Concern dan Prediksi Kebangkrutan Perusahaan. Jurnal Ilmiah Akuntansi, 5, 59-67.

Setyarno, E.B., I. Januarti, \& Faisal. (2006). Pengaruh Kualitas Audit, Kondisi Keuangan Perusahaan, Opini Audit Tahun Sebelumnya, Pertumbuhan Perusahaan terhadap Opini Audit Going Concern. Prociding, disampaikan dalam Simposium Nasional Akuntansi IX. Padang: 2326 Agustus.

Teoh, S.H., \& T. J. Wong. (1993). Perceived Auditor Quality and the Earnings Response Coefficient. The Accounting Review, 68(2), 346-366.

Watkins, R., D. Leigh, \& D. Triner, (2004). Assessing Readiness for E-Learning, Performance Improvement Quarterly, 17(4), 66-79. 